Article

\title{
Assessment of Climate Change Impact on Snowmelt Runoff in Himalayan Region
}

\author{
Rohitashw Kumar ${ }^{1}$, Saika Manzoor ${ }^{1}$, Dinesh Kumar Vishwakarma ${ }^{2,}$, , N. L. Kushwaha ${ }^{3}$, Ahmed Elbeltagi 4," \\ Kallem Sushanth ${ }^{5}$ and Alban Kuriqi ${ }^{6, *}$
}

1 College of Agricultural Engineering and Technology, Sher-e-Kashmir University of Agricultural Sciences and Technology of Kashmir, Shalimar Campus, Srinagar, Jammu, and Kashmir -190025, India; rohituhf@rediffmail.com (R.K.); saikamanzoor000@gmail.com (S.M.)

2 Department of Irrigation and Drainage Engineering, College of Technology, G. B. Pant University of Agriculture and Technology, Pantnagar, U.S. Nagar-263145 Uttarakhand, India;dinesh.vishwakarma4820@gmail.com (D.K.V.)

3 Division of Agricultural Engineering, ICAR-Indian Agricultural Research Institute, Pusa campus, New Delhi-110012; nand.kushwaha@icar.gov.in (N.L.K.)

4 College of Agricultural Engineering and Technology, Sher-e-Kashmir university of Agricultural sciences and Technology of Kashmir, Shalimar, Srinagar, Jammu and Kashmir;

4 Agricultural Engineering Dept., Faculty of Agriculture, Mansoura University, Mansoura 35516, Egypt; ahmedelbeltagy81@mans.edu.eg (A.E.)

5 Agricultural and Food Engineering Department, IIT Kharagpur, 721302, West Bengal, India.;kallemsushi@gmail.com (K.S.)

6 CERIS, Instituto Superior Técnico, University of Lisbon, 1649-004 Lisbon, Portugal; alban.kuriqi@tecnico.ulisboa.pt (A.K.)

* Correspondence: dinesh.vishwakarma4820@gmail.com (D.K.V.); +91 9670791406 ahmedelbeltagy81@mans.edu.eg (A.E.); alban.kuriqi@tecnico.ulisboa.pt (A.K.)

\begin{abstract}
The current study was planned to simulate runoff due to the snowmelt in the Lidder River catchment of Himalayan region under climate change scenarios. A basic degree-day model, Snowmelt-Runoff Model (SRM) was utilized to assess the hydrological consequences of change in climate. The SRM model performance during the calibration and validation was assessed using volume difference $(\mathrm{Dv})$ and coefficient of determination $\left(\mathrm{R}^{2}\right)$. The $\mathrm{Dv}$ was found as $11.7,-10.1,-11.8$, 1.96, and 8.6 during 2009-2014, respectively, while the $R^{2}$ is $0.96,0.92,0.95,0.90$, and 0.94 , respectively. The Dv and $\mathrm{R}^{2}$ values indicating that the simulated snowmelt runoff has a close agreement with the observed value. The simulated findings were also assessed under the different scenarios of climate change: a) increases in precipitation by $+20 \%$, b) temperature rise of $+2{ }^{\circ} \mathrm{C}$, and c) temperature rise of $+2{ }^{\circ} \mathrm{C}$ with a $20 \%$ increase in snow cover. In scenario "b", the simulated results showed that runoff increased by $53 \%$ in summer (April-September). In contrast, the projected increased discharge for scenarios "a" and "c" was $37 \%$ and $67 \%$, respectively. In high elevation data-scarce mountain environments, the SRM is efficient in forecasting future water supplies due to the snowmelt runoff.
\end{abstract}

Keywords: GIS; Himalayan region; SRM model; simulation; snowmelt runoff; climate change

\section{Introduction}

The study of hydrological behavior of catchment is an important and decisive approach in conservation and management of water resources [1-4]. The hydrologic cycle's key factor and component is the mountain snowpack storing winter precipitation and released in runoff and streamflow during spring and summer [5-6]. Snow is the primary and most significant water storage component in the basins, rendering places sensitive to the global warming and climate change [7]. Climate and streamflow data from mountainous places have shown a pattern of increasing winter minimum temperatures over 
the last several decades [8], and reduced snowfall compared to the total precipitation [9-10]. It is also indicated that decrease spring snow cover and snow depth [8] effects the streamflows in summer [11]. In studies across various countries, snow significantly impacts the surface moisture in a basin, which should be accessible for runoff in the future [12].

Like other parts of the globe, the maximum and minimum temperatures of Kashmir valley in the last 30 years are rose by $1^{\circ} \mathrm{C}$ and $0.5{ }^{\circ} \mathrm{C}$, respectively. Climate change impacts are already seen in the Himalayan River basins, such as rising air temperatures, decreased snowfall precipitation, and accelerated glacier melt [13] which resulted significant decrease in the discharge of Himalayan rivers [14]. According to current research programs, the surface temperature is increased by $0.74^{\circ} \mathrm{C}$ from 1906 to 2005 , with trends of warming in last 50 years is more [15]. Kashmir Himalayan glaciers have been observed to melt quickly due to global climate change [2], and mountains of Himalayan are melting at rapid rate (0.3-1.0 m/year) than the mean of world [16].

In predominant snowmelt basins, snow-covered area is an essential component for assessing, modeling, and forecasting meteorological, hydrological, and biological processes [17-18]. Data constraints have hampered thorough knowledge of variability in snow cover and melt of mountainous locations [19]. Snowmelt-runoff models are based on various concepts and assumptions. A fitting model is necessary to simulate the snowmelt runoff processes for the regions where the water resources are supplied by snowmelt runoff. Over the last four decades, several models have been developed worldwide to represent snowmelt runoff [20-21]. Hydrological models can be as simple as sand-filled boxes or as complex as computer programs. Several criteria can be applied to classify watershed models [22-23]. The Snowmelt Runoff Model (SRM) is a conceptual hydrologic model and most widely utilised for modeling and predicting the snow melt runoff in snow dominant areas [24].

Jain et al. [25] used the SRM to estimate runoff due to the rainfall and snowmelt for the Satluj basin, western Himalaya. The model was calibrated for 1996-1999 and runoff simulation was made for 2002-2005. Study revealed that model efficiency increased with temperature lapse rates. Similar attempt was made by Javadinejad et al. [26] to analyse the climate change effect on streamflow using SRM model. The result indicated that increase in the temperature, reduction in snow cover and precipitation. It is also concluded that the most of the runoff generated from the snow or ice melting. The viability of modeling snowmelt runoff in data-scarce watersheds using remote sensing data from snow and glacier cover, field measurements, Arc Geographic Information System (GIS) environment, and novel approaches to model parameterization [27-28]. Keeping in view the modeling importance, this study was conducted with objectives of simulation of streamflow of a basin using SRM model, and evaluate the model performance with climate change scenarios of temperature, precipitation, and snow cover on variation in streamflow.

\section{Materials and Methods}

\subsection{Study Area}

The Lidder watershed is selected in this study, which is situated in the upper Jhelum catchment, western Himalaya region. It has an area of $768 \mathrm{~km}^{2}$ and located in the longitude of $75^{\circ} 30^{\prime}$ to $75^{\circ} 45^{\prime}$ and latitude of $34^{\circ} 15^{\prime}$ to $34^{\circ} 30^{\prime}$. The catchment area elevation varies from 1800 to 5300 meters above mean sea level. This watershed consists around 3 $\%$ of the everlasting snow-cover in the whole watershed area and $6 \%$ in the upper watershed area. The Lidder watershed features 17 glaciers that encompass an area of around $40 \mathrm{~km}^{2}$ [29]. The largest glaciers of the Lidder watershed are Kolahoi $\left(10.2 \mathrm{~km}^{2}\right)$ and Shishram $\left(8.5 \mathrm{~km}^{2}\right)$ [30-31]. Figure 1 depicts the Lidder catchment location map. In the winter (December to March), the catchment receives significant snowfall, and melting in the summer. However, the catchment contains permanent snow cover and glaciers, so 
not all snow melts in the region. Figure 2 depicts the yearly precipitation and temperature observed at the Pahalgam station $(a-b)$. Snow is the most common kind of precipitation throughout the winter season. Although very variable, the area of snow cover in the Lidder watershed declines from roughly $90 \%$ (winter) to about $6 \%$ (autumn) [1].

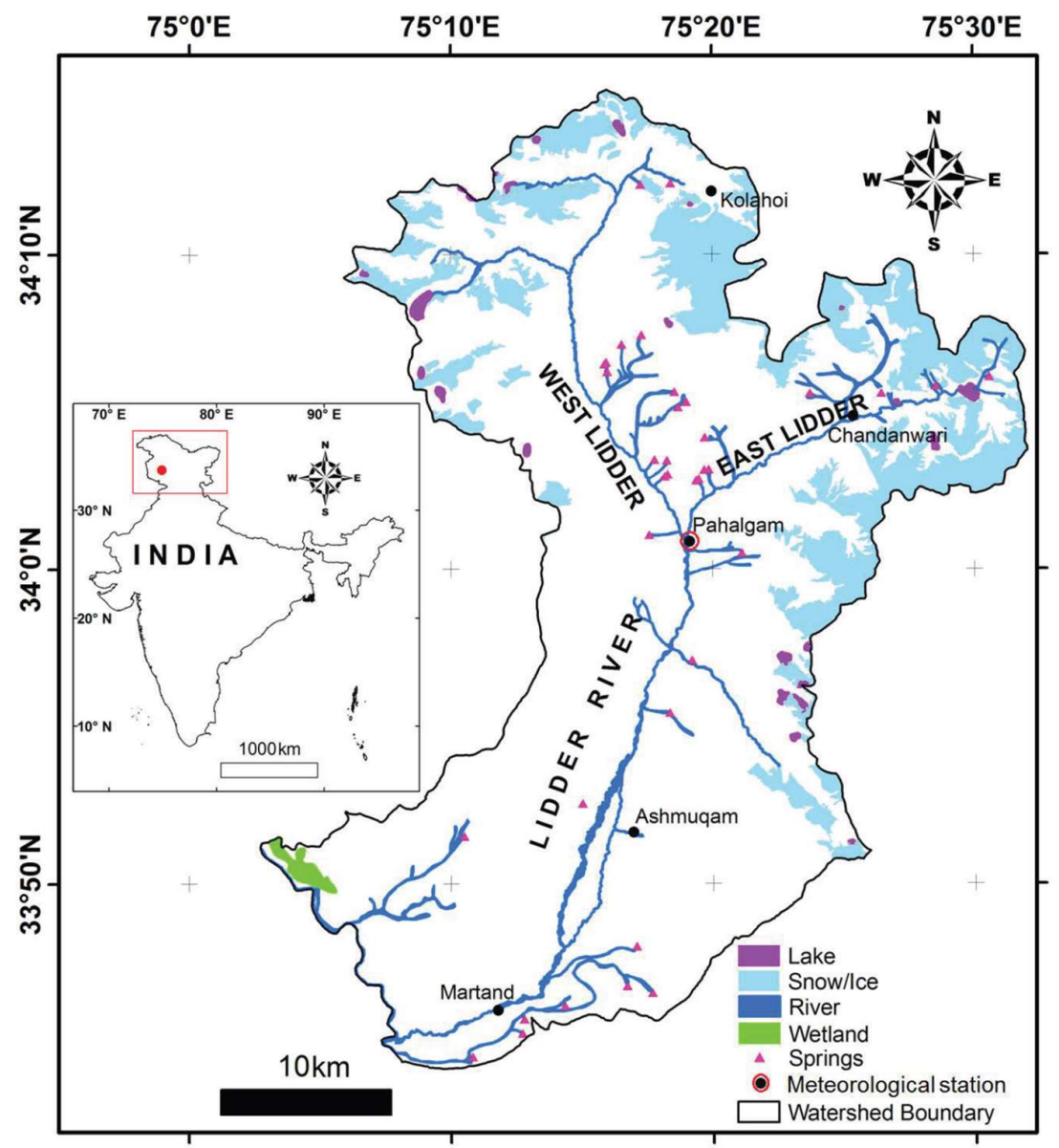

Figure 1. Location map of the study area: Lidder watershed.

(a)

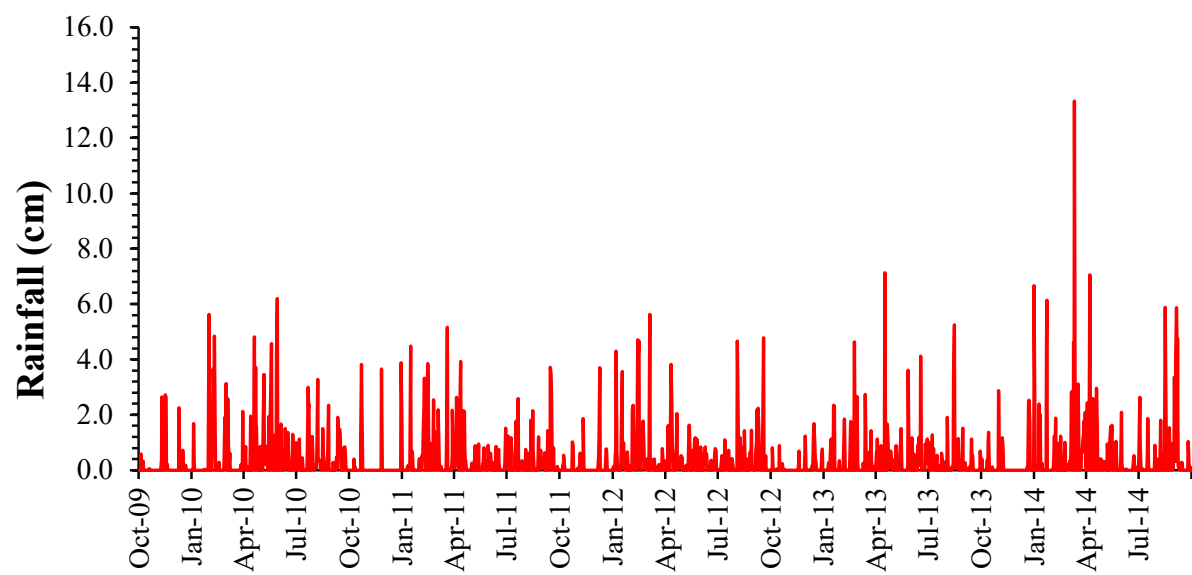

Time (days) 
(b)

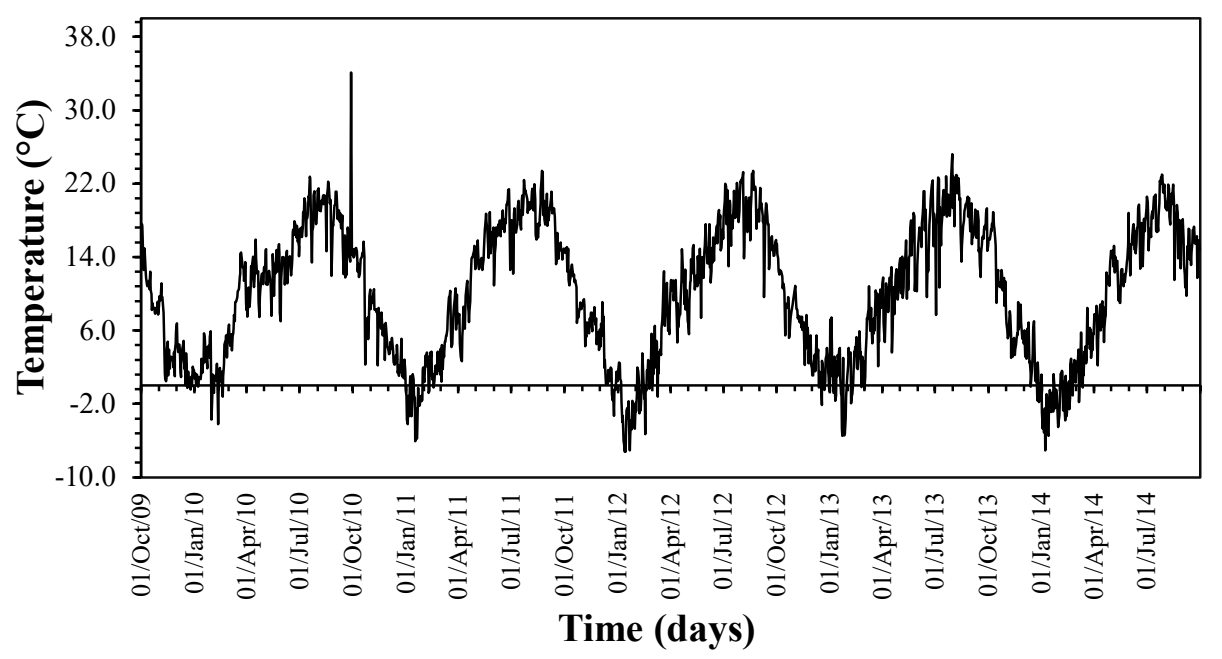

Figure 2. Monthly variations in (a) Precipitation (b)Temperature of Lidder basin during 2009-2014.

\subsection{Snowmelt Runoff Model (SRM)}

The SRM is intended to model and estimate streamflow in the snow regions daily where melting snow plays a significant role in the runoff. Martinec [32] created SRM for small basins. To cover bigger basins, the model can be ascribed to remote sensing of snow cover. The important input parameters of SRM are precipitation, air temperature, and per cent area snow cover. SRM accounts for degree-days by splitting the watershed into elevation zones to calculate snowmelt. The SRM contains two parts in the present study. The first is to simulate the snow movement for estimating the daily snow cover area and snow storage. Another is the hydrologic process, including precipitation, snow melting, transpiration, recharge, and discharge accumulation.

The basin is classified into several elevation zones in SRM. Every day, snowmelt is forecasted in each zone based on rainfall and air temperature. The entire new water is directed through single storage. The model's original form can be expressed by a single equation:

$$
Q_{n+1}=k Q_{n}+(1-k) \sum\left(\alpha_{i} T_{i} A_{i}+P_{i}\right)
$$

Where $Q=$ discharge from the basin $\left(\mathrm{m}^{3} / \mathrm{s}\right), k=$ recession coefficient, $\alpha=$ degree-day factor $\left[\mathrm{cm}^{\circ} \mathrm{C}^{-1} \mathrm{~d}^{-1}\right]$ indicating the snowmelt depth from one degree-day, $T=$ air temperature $\left({ }^{\circ} \mathrm{C}\right)$ extrapolated to the hypsometric mean height of each zone, $A=$ current snow-covered area in the zone (\% of zone area), $P=$ precipitation $(\mathrm{mm})$ falling as rain in the zone (When $T>T_{\text {crit }}$ ), $n=$ sequence of day during simulation period.

$T_{i}$ can be extrapolated from the temperature at base station using a temperature lapse rate which is also implied in the equation (1). SRM version- 4 is slightly more sophisticated and includes extra parameters, but the core framework remains constant. Version-4 of SRM is represented by the equation (2) given below:

$Q_{n+1}=k_{n+1} Q_{n}+\left(1-k_{n+1}\right) \sum\left(C_{S n} a_{i} T_{i} A_{i}+C_{R n} P_{i}\right)$

Where $C_{S n}=$ correction factor for losses from snowmelt, $C_{R n}=$ correction factor for losses fromrainfall.

The following equation represents the current version of SRM:

$Q_{n+1}=\left[C_{S n} \alpha_{n}\left(T_{n}+\Delta T_{n}\right) S_{n}+C_{R n} P_{n}\right] \frac{A \cdot 10000}{86400}\left(1-k_{n+1}\right)+Q_{n} k_{n+1}$ 
Where $\Delta T=$ the adjustment by temperature lapse rate when extrapolating the temperature from the station to the average hypsometric elevation of the basin or zone $\left[{ }^{\circ} \mathrm{C} / \mathrm{d}\right]$.

Equation (3) starts with a lag of 18 hours between the daily discharge and temperature cycles. In this scenario, the $n+1^{\text {th }}$ day discharge is depends on the measured degree-days on the $n^{\text {th }}$ day. These factors can be measured or calculated using empirical regression relationships and hydrological judgment based on basin features. The snowmelt depths were calculated using the degree-day factor. The degree-day factor for snow is determined by the Snow density data, which is strong indication of albedo. There is no information known on the snow density in the area. The crucial temperature is calculated based on the kind of precipitation. The critical temperature during the snowmelt season is essential for SRM to determine whether the rainfall or snow fall $\left(T<T_{\text {crit }}\right)$ instantly contributes to runoff.

\subsection{Input Data and Parameter}

The required inputs for this study were daily precipitation, temperature, and snow-cover, based on which discharge can be calculated. Weather data was collected from the India Meteorological Department, Rambagh. Precipitation is most spatially variable among all the variables of meteorology. The precipitation, maximum and minimum temperatureare collected from the IMD on a daily basis. The maximum and the minimum temperature values are averaged to get the daily average temperatures fed in the model. Weather data and observed runoff data for five years (2009-2014) were fed into the model. Moderate Resolution Imaging Spectroradiometer (MODIS) remote sensing data of snow cover is used for estimating the snow cover percentage from 2009-2014, which is explained in-detail in Section 2.4. Snow cover measurements in various elevation zones need the use of a Digital Elevation Model (DEM) for computations. The ADvanced Spaceborne Thermal Emission and Reflection Radiometer (ASTER) DEM is suitable for high-latitude and steep mountainous locations, which Shuttle Radar Topography Mission (SRTM) does not cover. The ASTER DEM tiles can be downloaded electronically for the Lidder catchment from https://wist.echo.nasa.gov/wist/api/imswelcome/ web page. The catchment region was extracted using ASTER DEM data and the Integrated Land and Water Information System (ILWIS).

Input parameters of the SRM were degree-day factor, temperature lapse rate, lag time, lag time, contributing rainfall area, snow and rain runoff coefficients, and recession coefficients. These factors were produced from measurements and approximated using judgment based on the Himalayas' hydrological properties, physical laws, theoretical and empirical regression relationships [33]. Most of the input parameters are dynamic in nature, changing spatially and temporally [24], implying that a particular set of parameters might not be appropriate for every year. The range of the SRM input parameters is summarized in Table 1. The parameter values were set in the range presented in the table upon calibration of the model till the simulated runoff values were adjusted close to the observed runoff.

Table 1. SRM model final input parameters values.

\begin{tabular}{ll}
\hline Parameters & Values \\
\hline
\end{tabular}




\begin{tabular}{cc}
\hline Degree-day factor & 0.5 \\
Runoff coefficient (rain) & $0.1-0.4$ \\
Runoff coefficient (snow) & $0.1-0.4$ (October-February) \\
& $0.5-0.7$ (March-September) \\
Temperature lapse rate $\left({ }^{\circ} \mathrm{C} / 100 \mathrm{~m}\right)$ & 0.44 \\
Critical Temperature $\left({ }^{\circ} \mathrm{C}\right)$ & 0.8 \\
Lag Time (hours) & 18 \\
Recession Coefficient & 1.03 and 1.04 \\
X-Coefficient & 0.01 and 0.03 \\
Y-Coefficient &
\end{tabular}

\subsection{Snow-cover estimation}

Because of the substantial spatial-temporal variation in snow cover and the data available in the research region, images derived from satellite sensors appear to be the best source for estimating snow cover [34]. In this investigation, MODIS images were utilized to estimate snow cover. With the launch of MODIS in December 1999, a progressive development was started in hyperspectral satellite remote sensing. The MODIS allows for environmental monitoring by assessing aerosol concentrations and gas traces in the air, and mapping the land, sea and clouds in many spectral bands. The MODIS collects the data worldwide for each 1-2 days and has a repetition cycle of 16 days.

In this study, MOD10A2, a MODIS snow product was utilized, which gives the information for extent of snow coverage in a repeating period of 8 days [35]. Mapping of snow cover was the time-consuming task in this study since satellite images were obtained daily and processed for snow-cover extraction if the study region was cloud-free. The file size was excessive, and a significant number of images were necessary. From January 2009 to December 2014, a total of 264 processed MOD10A2 images were gathered from http://nsidc.org/cgi-bin/snowi/search.pl. Geo-referencing was carried out for all the Hierarchical Data Format (HDF) images. The images for the Lidder River Catchment were re-projected in ArcGIS 10.2 using the WGS 1984 Universal Transverse Mercator (UTM) Zone $43 \mathrm{~N}$ projection method. If the percentage of cloud cover on a certain day surpassed $20 \%$, the record was removed. For that day, the snow coverage was approximated by linearly interpolating the preceding and succeeding accessible images which are cloud-free images. The snow pixels were multiplied by cell area and then converted to square kilometers with each 8-day interval value divided by the area of the basin and interpolated to get values of daily snow cover.

\subsection{Calibration and Validation of Model}

Before applying the model to a real-world situation, it must be calibrated and validated. This procedure was carried out to make a credible forecast that co-relates the observed value to a higher extent. Because it takes regional heterogeneity into account, the SRM model has a large number of parameters. These parameters were calculated using a calibration procedure because they could not be acquired directly from existing data. Calibration was performed manually in the current study by altering input parameters. After calibration, adequate validation is required for model testing before it can be utilized under different situations. In the validation procedure, the model parameters defined in the calibration were used. The results were compared with the observed data to assess model prediction performance. The data for the hydrological years (October to September) 2009-10 was used for calibration, while data for hydrological years 2010-14 was used to validate the model.

\subsection{Model Accuracy}


The SRM computer program involves the assessment of model accuracy by the graphical representation of the estimated hydrograph and observed runoff. In addition to the plots, the SRM uses two performance indices: the percent volume difference (Dv) and coefficient of determination $\left(R^{2}\right)[24,36]$. The coefficient of determination is estimated as follows:

$$
\mathrm{R}^{2}=1-\frac{\sum\left(\mathrm{Q}_{\mathrm{obs}}-\mathrm{Q}_{\mathrm{cal}}\right)^{2}}{\sum\left(\mathrm{Q}_{\mathrm{obs}}-\overline{\mathrm{Q}}_{\mathrm{obs}}\right)^{2}}
$$

Where $Q_{o b s}=$ measured daily discharge, $Q_{c a l}=$ simulated daily discharge, $\bar{Q}_{o b s}=$ average measured discharge.

$R^{2}$ value shows that the measured and simulated (calculated) values coincide perfectly and would plot as 1:1 [41]. The Dv is computed as follows:

$$
\mathrm{D}_{\mathrm{v}}[\%]=\frac{\left(\mathrm{V}_{\mathrm{obs}}-\mathrm{V}_{\mathrm{cal}}\right)}{\mathrm{V}_{\mathrm{obs}}} \times 100
$$

Where $V_{o b s}=$ the measured melting season runoff volume, $V_{c a l}=$ the computed melting season runoff volume. The negative $\mathrm{Dv}$ value indicates an underestimating of the streamflow, whereas positive value indicates an overestimation.

\subsection{Climate Change Impact Detection}

The variance of streamflow in mountainous areas is primarily driven by changes in the space and time distribution of precipitation, and melting of snow induced by rising temperatures. In the Lidder river watershed, the runoff is mainly caused by snowmelt, making it highly exposed to the climate change. Analytical studies revealed that a temperature rises of $1-3{ }^{\circ} \mathrm{C}$ in the western Himalayan region can increase the $16-50 \%$ of glacier melt runoff [37]. Therefore, it is critical to employ accurate hydrological methods to predict runoff caused by the snowmelt, especially in high elevation areas. under future scenarios of climate change. Furthermore, the SRM is used to model the climate change impact on Lidder River discharge. Three potential climate change scenarios were constructed in the WinSRM model and are mentioned below.

Scenario-A: $+20 \%$ increase in precipitation.

Scenario-B: $+2{ }^{\circ} \mathrm{C}$ rise in temperature and

Scenario-C: $+2^{\circ} \mathrm{C}$ rise in temperature and $20 \%$ increase in snow cover.

In mountainous regions, variation in river discharge is mainly influenced by (1) changes in the spatial and temporal distribution of precipitation and (2) melting of snow cover and glaciers, which is caused by increased temperature. Therefore, we described future climate change scenarios using downscaled GCM simulation data and considered the impact of rainfall, snowmelt, and glacial melting on streamflow.

Four scenarios were described: In scenario 1, the change in cryosphere area was not considered, while the mean temperature and precipitation were changed based on the statistical downscaling results of HadCM3 (Hadley Centre Coupled Model, version 3) in the SRES A2 scenario. In scenario 2, the change in cryosphere area was not considered, while the mean temperature and precipitation area changed based on the statistical downscaling results of HadCM3 in the SRES B2 scenario. In scenario 3, the mean temperature and precipitation were changed based on the statistical downscaling results of HadCM3 in the SRES A2 scenario, and the cryosphere area was assumed to increase or decrease by $20 \%$. In scenario 4 , the mean temperature and precipitation were changed based on the statistical downscaling results of HadCM3 in the SRES B2 scenario, and the cryosphere area was assumed to increase or decrease by $50 \%$.

\section{Results and Discussion}

The simulation of runoff produced by the snowmelt and rainfall is crucial for planning water management programs. In this study, streamflow in the Lidder river Catchment is model is simulated by the SRM. The SRM is later run for the hypothetical sce- 
narios of change in climate to investigate its implications on the flow pattern. The investigation results are presented and discussed herein under suitable headlines by providing reasoning in the light of available literature and field study.

\subsection{Snow Cover}

In the given time period, the snow-covered area changed to the non-snow-covered area after melting in the various months. The average area of snow cover varies from 10 $\%$ to $90 \%$. The area has a maximum snow cover of $80-90 \%$ during the winter (December to February) season, and a least snow cover (10-15\%) is observed in the summer (June to September) season. The computed snow cover is shown in Figure 3, which depicts snow cover distribution in the Lidder River watershed from 2010 to 2014 . According to Figure 3, 2014 had the most snow (49\% snow cover), while 2010 had the least snow (34 \% snow cover). The river discharge mainly depends on change in snow covered area. When the snow cover data is compared with the observed streamflow data, the discharge is lowest in the winter season. As the mean temperature rise in April, the discharge begins to rise, particularly in low elevation snow cover regions. The flow peaks in July, when glacial melt begins following the melting of new snow in the watershed.

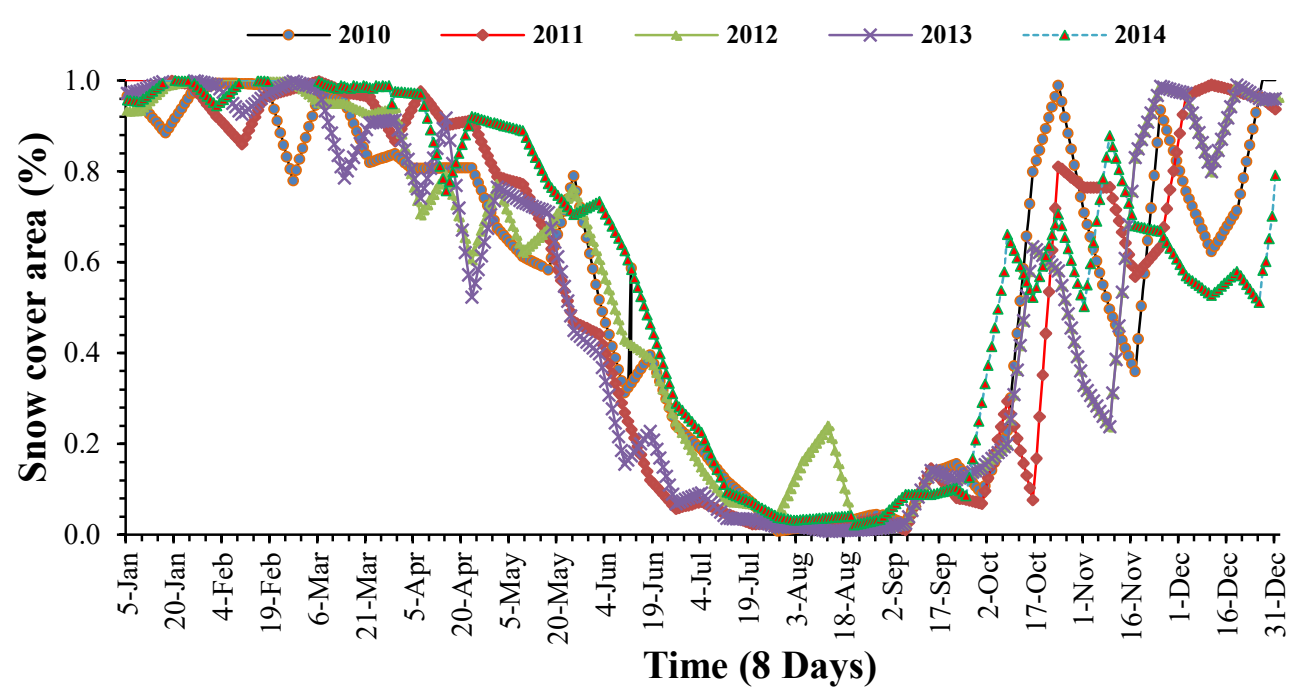

Figure 3. Snow cover distribution of the Lidder basin.

\subsection{Model Calibration}

The catchment's runoff due to the snowmelt was modeled using SRM. Water losses are often relatively minor during the start of the snowmelt season since the only outcome is the evaporation from the snow cover. As the soil gets uncovered and vegetation tends to develop, high water losses are predicted due to evapotranspiration and interception from the vegetation. First, the model was run without making any changes in the parameters for pre-calibration using discharge data for the hydrological year 2009-10, and results were recorded. The SRM model performance at a daily scale was evaluated by plotting a graph between the streamflows of simulated and observed. Furthermore, the performance of the model was assessed using the Dy and R2 values between simulated and observed streamflow. The simulated and observed discharge value in different months in pre-calibration is illustrated in Figure 4. It is evident from Fig. 4 that the model mostly overestimates the discharge than the observed values in different months. It is also observed from Figure 4 that the model overestimated the runoff in the melting season. The simulated discharge values are found both higher and lower than the ob- 
served values in different months. The $\mathrm{R}^{2}$ value was found 0.90 in the pre-calibration of the model. The highest value of discharge for pre-calibration is observed in June.

The calibration was conducted manually by running the SRM model numerous times for the 2009-2010 year, yielding an optimum value of the degree-day parameter for the watershed that ranges between 0.1 and $0.4 \mathrm{~mm} \mathrm{~d}-1{ }^{\circ} \mathrm{C}-1$. After numerous iterations of fine-tuning the model, the optimal values for the critical temperature the lag time, and the recession coefficient are determined. The SRM model was calibrated for the 2009-2010 years. Figure 5 shows the calibrated results of simulated and observed runoff. According to Figure 5, the field observed and simulated discharge are matched well. Also, the maximum discharge is recorded in June during calibration. During calibration, the model's accuracy requirements provide a volume difference (Dv) of $11.7 \%$ and an R2 value of 0.96 . The simulation error indication indicates that the simulation is adequate for both daily and seasonal melting.

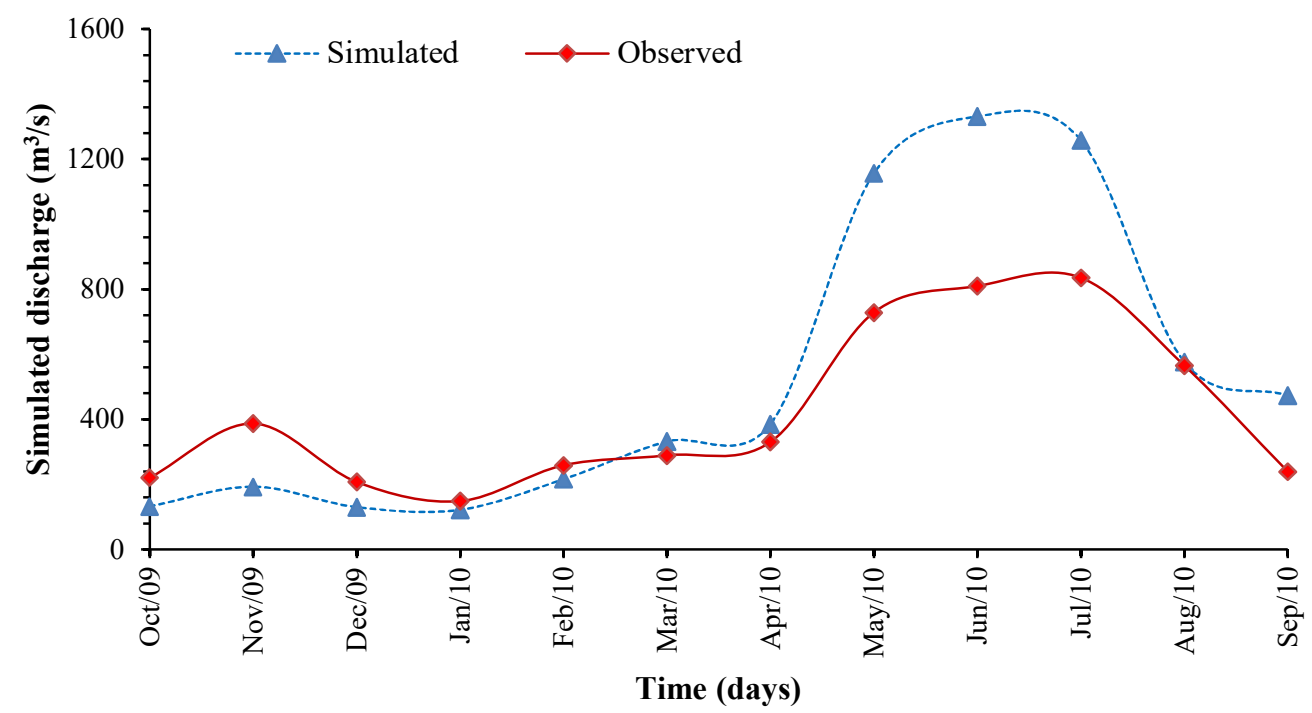

Figure 4. Simulated and observed discharge in different months for the basin's the hydrological year 2009-2010 (pre-calibration).

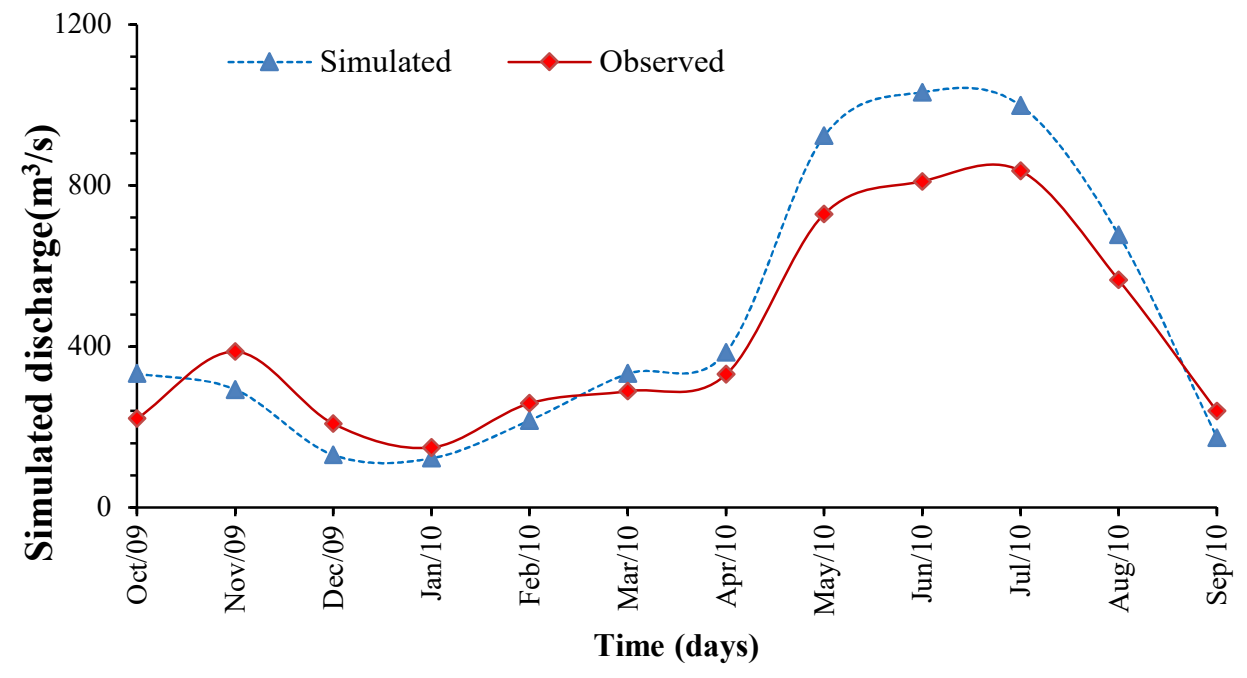


Figure 5. On calibration, the model simulated and observed discharge in different months of the hydrological Year 2009-10 of the Lidder basin.

\subsection{Model Validation}

After calibrating the model, it is transferred to another year by simply adjusting the input data for that year but not the calibrated parameters. The model was validated for the hydrological years 2010-11 to 2013-14 on yearly basis, with the same parameters used during calibration. The graphical representation between simulated and observed discharge of year 2010-11 is given in Figure 6. It can be observed from Figure 6 that the simulated and the observed values for the discharge are in close agreement. It also observed that the highest value of discharge was found in June $\left(869.8 \mathrm{~m}^{3} / \mathrm{s}\right)$. The performance indices during the year $2010-11$ are found as $\mathrm{Dv}=-10.1 \%$ and $\mathrm{R}^{2}=0.92$. The model slightly overestimates the discharge value; however, the difference is within reasonable limits. The model validation results also showed that the simulated and the observed values matched well, and the statistical parameters were within a reasonable range.

Further, the model was run for the year 2011-12. The validation run shows the highest value of discharge in July. The graphical representation between modelled and field observed value of discharge is shown in Figure 7. The modeled value and observed values were found in good agreement with $\mathrm{Dv}$ of $-11.8 \%$ and $\mathrm{R}^{2}$ of 0.95 . Similarly, the SRM model was run for 2012-13 (Figure 8). It is evident from Fig.8 that the model performance is good and the highest discharge value found in July $(1176.68 \mathrm{~m} 3 / \mathrm{s})$. The modeled and observed values were found in good agreement with the Dv value of $1.96 \%$ and $R^{2}$ value of 0.90 . The simulated values and observed values of year 2013-14 are plotted, and found a good agreement with Dv of $8.6 \%$ and R2 of 0.94 (Figure 9). The maximum discharge can be observed in September of 2013-14 (4381.57 m3/s) compared to all the years because of excessive floods in that year.

For whole time period (2009-2014) including calibration and validation, the yearly statistical error results indicating that the model performance is very good. However, it is also observed that the model overestimates and underestimates the streamflow at different times. The values were in high accuracy compared to the previous studies [38, 33] conducted in the other regions of the world. The average value of the $\mathrm{R}^{2}$ and Dv during the whole simulation period was found as 0.92 and $0.072 \%$, respectively. The values of the statistical indicators are in close range as obtained during calibration and validation.

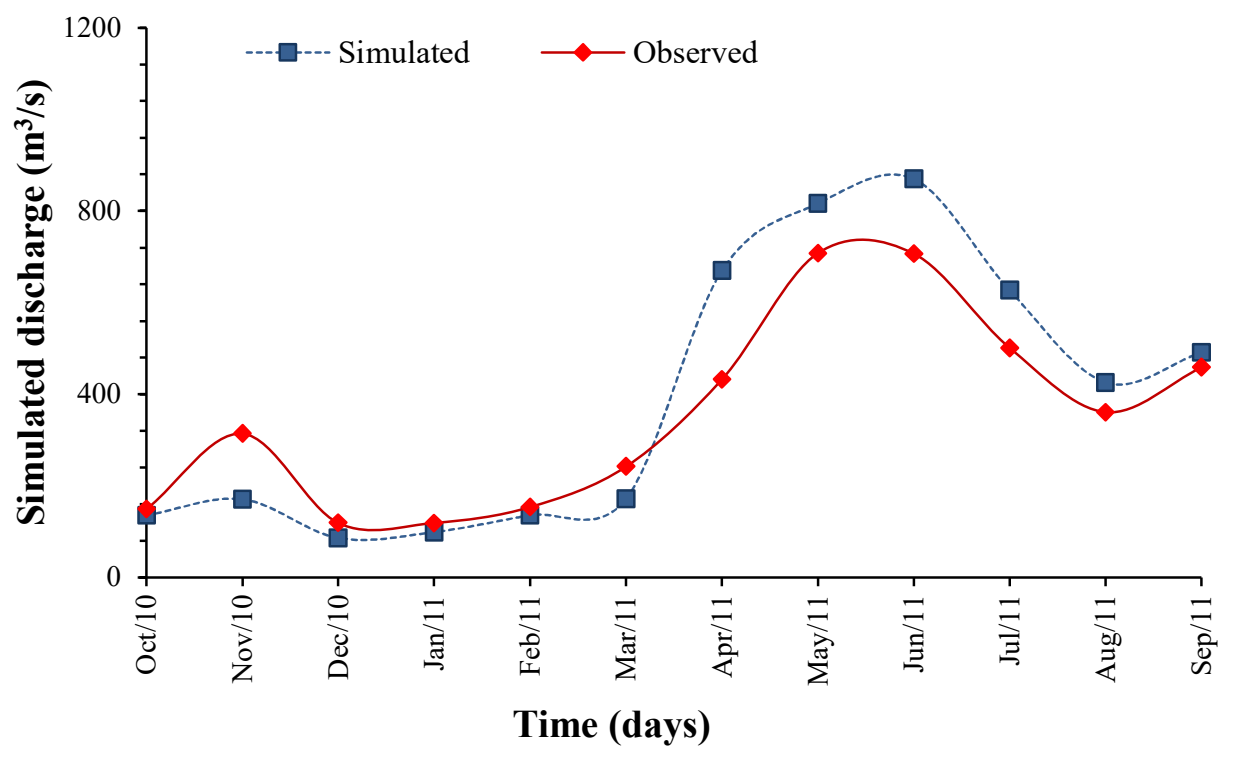


Figure 6. On validation, the model simulated and observed discharge in different months of the hydrological Year 2010-11 of the Lidder basin

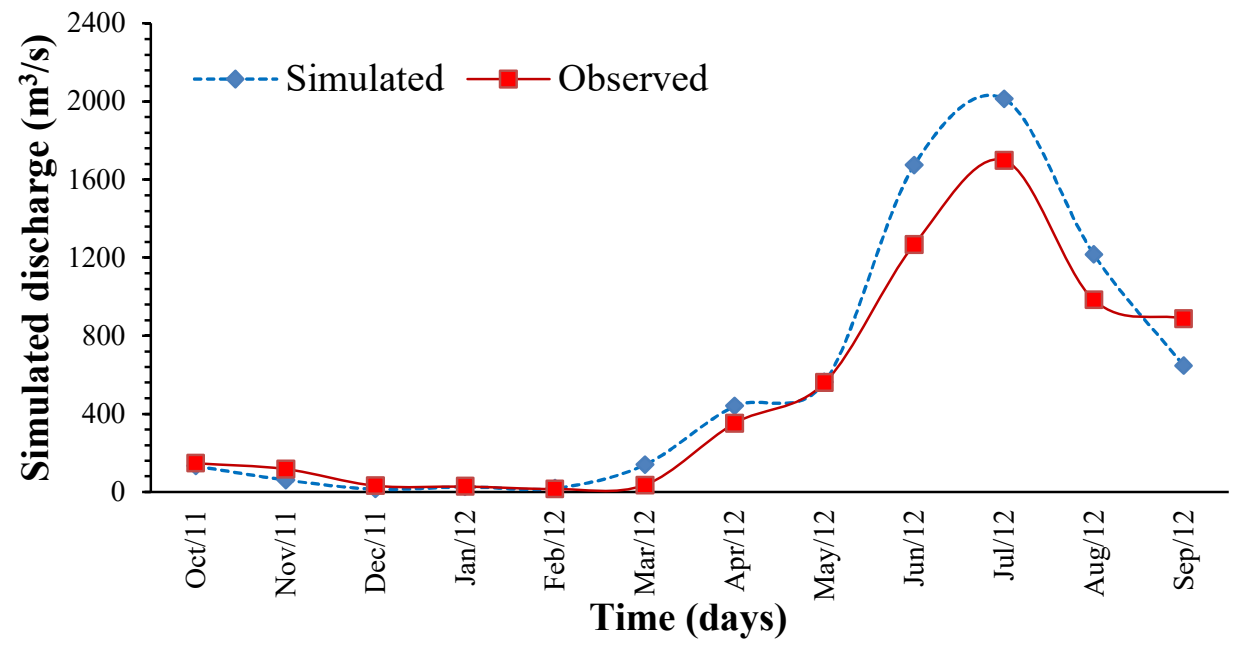

Figure 7. On validation, the model simulated and observed discharge in different months of the hydrological Year 2010-11 of the Lidder basin

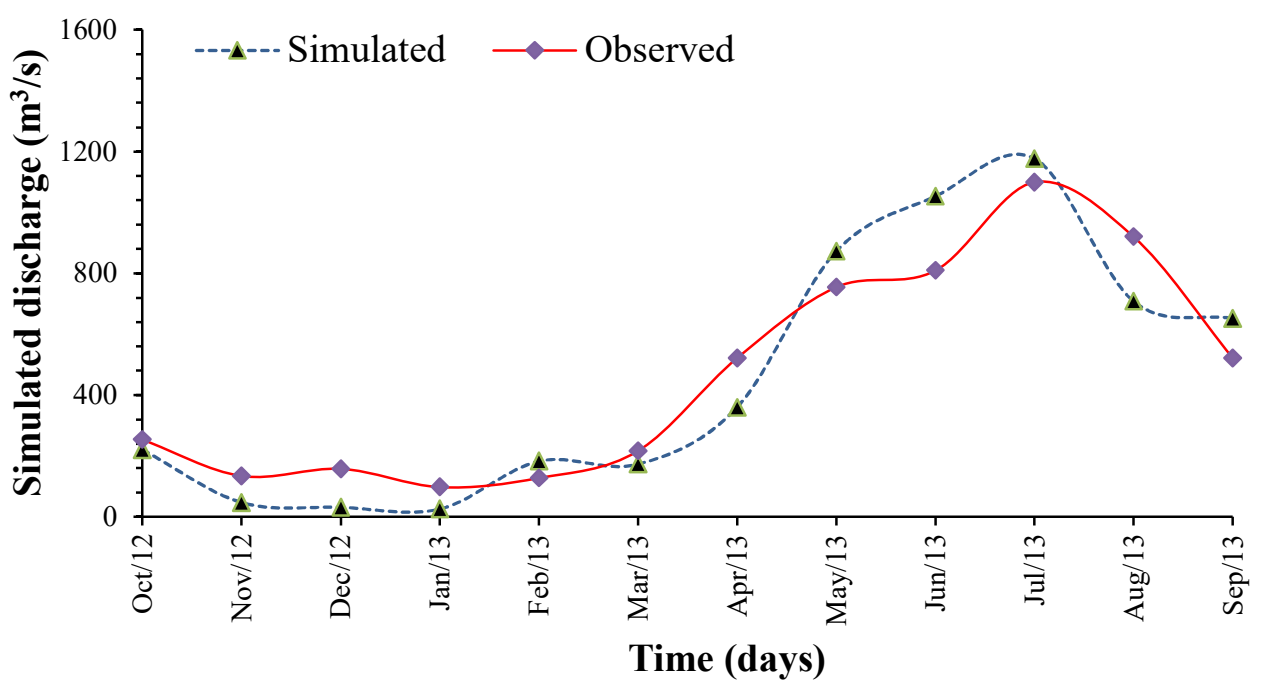

Figure 8. On validation, the model simulated and observed discharge in different months of hydrological Year 2012-13 of the Lidder basin.

These findings imply that the SRM accuracy obtained in this work is excellent and may be used for runoff modeling in other Himalayan basins for water resource management and planning.

\subsection{Climate Change Impact on Stremflow}

The impact of climate change under the three scenarios (mentioned in Section 2.7) was assessed using a simulation period of 2011-12. The discharges simulated foe each month of hydrological year 2011-12 under all scenarios are summarized in Table 2. Figure 10 depicts the discharge variation in all three scenarios.

In Scenario-A, according to the findings, summer streamflow is predicted to rise as the snow cover area increases. If the mean temperature stays constant, a $20 \%$ increase in 
precipitation leads to an approximately $37 \%\left(2441 \mathrm{~m}^{3} / \mathrm{s}\right)$ increase in average discharge in summer (April-September) above the current average summer discharge $\left(6553 \mathrm{~m}^{3} / \mathrm{s}\right)$ [39]. The peak discharge was the highest in July $(2013.44 \mathrm{~m} 3 / \mathrm{s})$ in the simulated discharge values for 2011-12 as the current year. In contrast, with the change in precipitation by 20 $\%$, the peak discharge was shifted by one month earlier in June $\left(2460.11 \mathrm{~m}^{3} / \mathrm{s}\right)$.

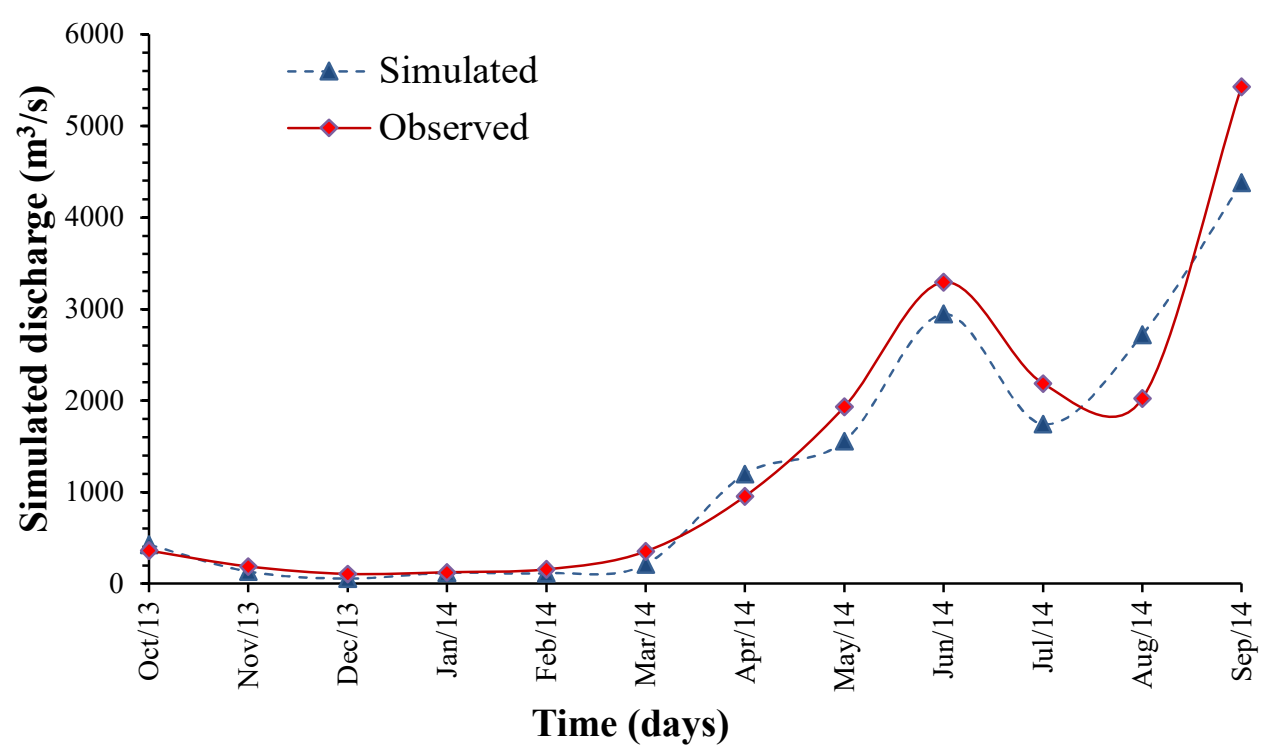

Figure 9. On validation, the model simulated and observed discharge in different months of hydrological Year 2013-14 of the Lidder basin.

In Scenario-B, the results illustrated in Table 2 indicated that an increase in temperature $2{ }^{\circ} \mathrm{C}$, resulted in an increase of $53 \%\left(3476 \mathrm{~m}^{3} / \mathrm{s}\right)$ in the average discharge in summer. The peak discharge was observed highest in July $\left(2013.44 \mathrm{~m}^{3} / \mathrm{s}\right)$. The temperature change by $2^{\circ} \mathrm{C}$, the peak discharge was shifted by one month in June $\left(2853.29 \mathrm{~m}^{3} / \mathrm{s}\right)$. This result indicated that if rise in the air temperature continues at the rate of $3.7^{\circ} \mathrm{C}$ [15], then runoff must be carefully managed due to the large volumes of runoff received from the Lidder and its adjoining glacier and snow melt regions.

The increase in temperature also results, change in a time where peak flow occurs, from June to July (Figure 10). If this scenario continues, the glaciers may recede significantly or perhaps vanish after a time. Cannone et al. [40] reported on the fast melting of glaciers, explaining that number of small glaciers (covers $80 \%$ of total area under glaciers and an essential for providing the water supply) might vanish in the coming decades due to the present warm climatic trend. These vanishing glaciers affect the hydrograph by changing the surface albedo and soil water storage capacity.

The discharge simulated under the condition of a $20 \%$ increase in snow cover and a $2 \%$ increase in mean temperature (Scenario-C), resulting in a $67 \%$ increase in streamflow. The peak discharge was observed to be the highest in July $\left(2013.44 \mathrm{~m}^{3} / \mathrm{s}\right)$ in the simulated discharge values for the year 2011-12 as the current year, whereas with the increase in temperature by $2{ }^{\circ} \mathrm{C}$ and the increase in precipitation by $20 \%$, the peak discharge was shifted by one month to June $\left(2944.30 \mathrm{~m}^{3} / \mathrm{s}\right)$. These findings suggested that the discharge impacts the snow cover melt produced by the average temperature in summer. It is evident from Figure 10 that the streamflow increases with the variations in the hydro-meteorological parameters. The impact of climate change research revealed that the hydrology of catchment would affect under climate change scenarios. This shift appears to be the effect of rising temperatures, which increased the streamflow of summer in the region. The snowmelt runoff appears to fluctuate in spring as precipitation and mean temperature rise, even though the climatic scenarios employed in this study 
give important information regarding how steam flow varies with temperature, precipitation, and snow cover.

According to the Intergovernmental Panel on Climate change (IPCC) scenarios, future climate change was noticeable by various impacts. Figure 11 depicts the precipitation changes in the Lidder river watershed under the A2 and B2 scenarios from the year 2020 to 2080. It is indicated that the future annual precipitation in the Lidder river catchment is decreasing. From the A2 and B2 scenarios, it is evident that the monthly precipitation is decreasing throughout spring, summer, and fall and a rising tendency during the winter. Figure 12 depicts the average changes in mean temperature in both the scenarios from the year 2020 to 2080 . On a seasonal basis, there is a growing tendency for the future mean temperature, and the increasing range under A2 is greater than B2.

In this investigation, the year 2010-11 is used as a reference year for the above climate scenarios. In the 2020, the mean precipitation was predicted to decline in spring and summer as $1.2 \%$ and $3.8 \%$, respectively. At the same time, mean watershed temperatures were predicted to climb $1.5^{\circ} \mathrm{C}$ in both seasons. In the 2050, average precipitation was predicted to decline in spring and summer as $0.3 \%$ and $4.8 \%$, respectively. At the same time, average temperature of the catchment was predicted to climb in spring and summer as $1.8{ }^{\circ} \mathrm{C}$ and $2.2{ }^{\circ} \mathrm{C}$, respectively. In the 2080s, average precipitation in spring and summer is declined as $1.7 \%$ and $12.1 \%$, respectively. At the same time, catchment average temperatures were predicted to climb $3.1^{\circ} \mathrm{C}$ and $3.4{ }^{\circ} \mathrm{C}$, respectively. The results show that streamflow in the spring is expected to increase with increasing mean temperature, whereas streamflow in the summer declines with decreasing precipitation. The average streamflow during the summer seasons is down $4.3 \%$ in the 2020 s but up $1.5 \%$ and $10.1 \%$ in the $2050 \mathrm{~s}$ and $2080 \mathrm{~s}$, respectively. The findings also suggest that as the snow cover area increases, streamflow will increase in the spring and summer. The mean discharge increases by $12.6 \%$ during the snowmelt seasons due increase in snow cover percentage (i.e., $20 \%$ ).

Table 2. Climate change run of SRM with change in precipitation, temperature, and snow cover.

\begin{tabular}{ccccc}
\hline \multirow{2}{*}{$\begin{array}{c}\text { Climate hange } \\
\text { run }\end{array}$} & $\begin{array}{c}\text { Simulated } \\
\text { Discharge } \\
\text { of } \mathbf{2 0 1 1 - 1 2} \\
\left(\mathbf{m}^{3} / \mathbf{s}\right)\end{array}$ & $\begin{array}{c}\text { With } 20 \% \text { increase } \\
\text { in precipitation }\end{array}$ & $\begin{array}{c}\text { With temperature } \\
+2^{0} \mathbf{C}\end{array}$ & $\begin{array}{c}\text { With temperature }+2^{\circ} \mathrm{C} \\
\text { and } 20 \% \text { Snow cover }\end{array}$ \\
\hline October & 132.52 & 199.34 & 197.72 & 263.52 \\
November & 61.33 & 62.82 & 156.03 & 164.27 \\
December & 14.48 & 34.82 & 50.86 & 53.08 \\
January & 26.09 & 26.62 & 29.44 & 29.44 \\
February & 19.16 & 19.55 & 21.71 & 21.71 \\
March & 139.25 & 79.27 & 239.42 & 245.61 \\
April & 439.55 & 1107.84 & 1581.14 & 1635.27 \\
May & 562.03 & 1580.13 & 2067.09 & 2138.59 \\
June & 1674.45 & 2460.11 & 2853.29 & 2944.30 \\
July & 2013.44 & 1363.84 & 1110.06 & 1479.76 \\
August & 1216.13 & 1396.28 & 1351.77 & 1531.65 \\
September & 647.41 & 1086.18 & 1065.63 & 1205.03 \\
\hline
\end{tabular}




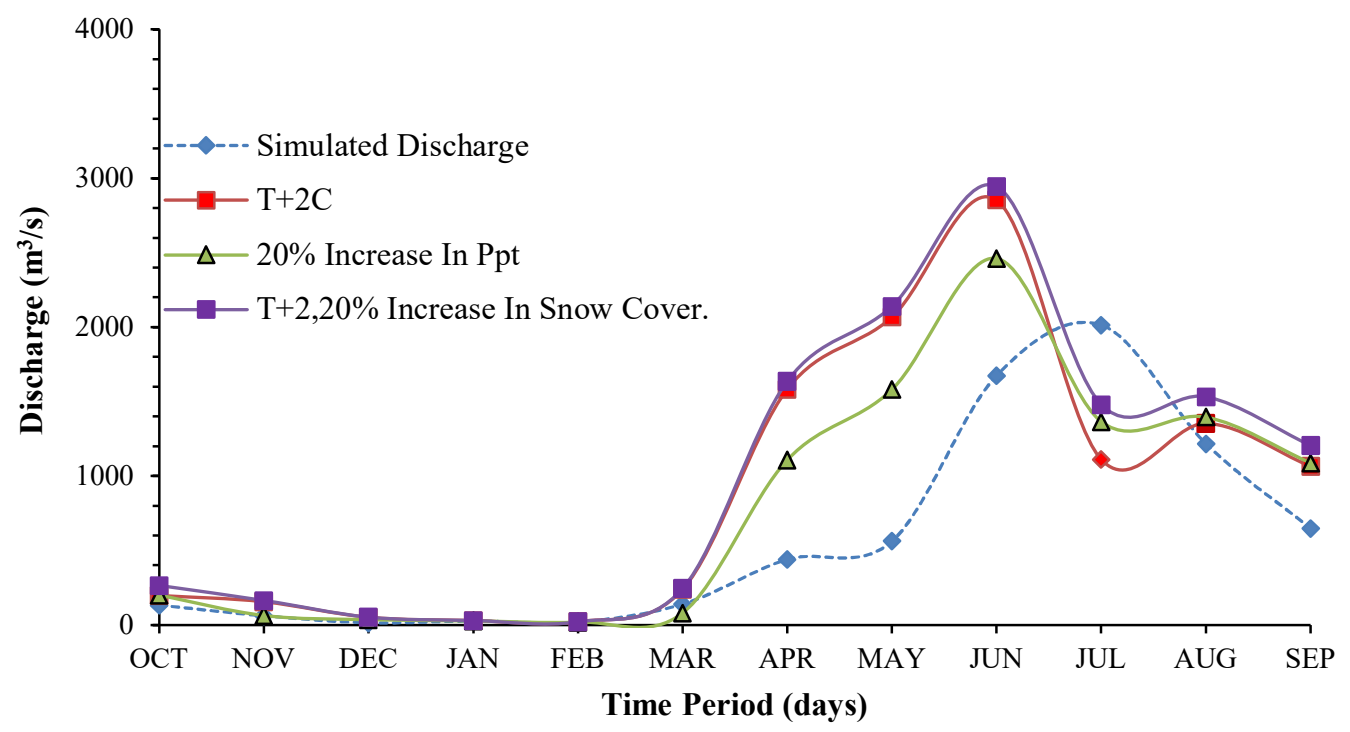

Figure 10. Climate change run of SRM with change in temperature, precipitation, and discharge.

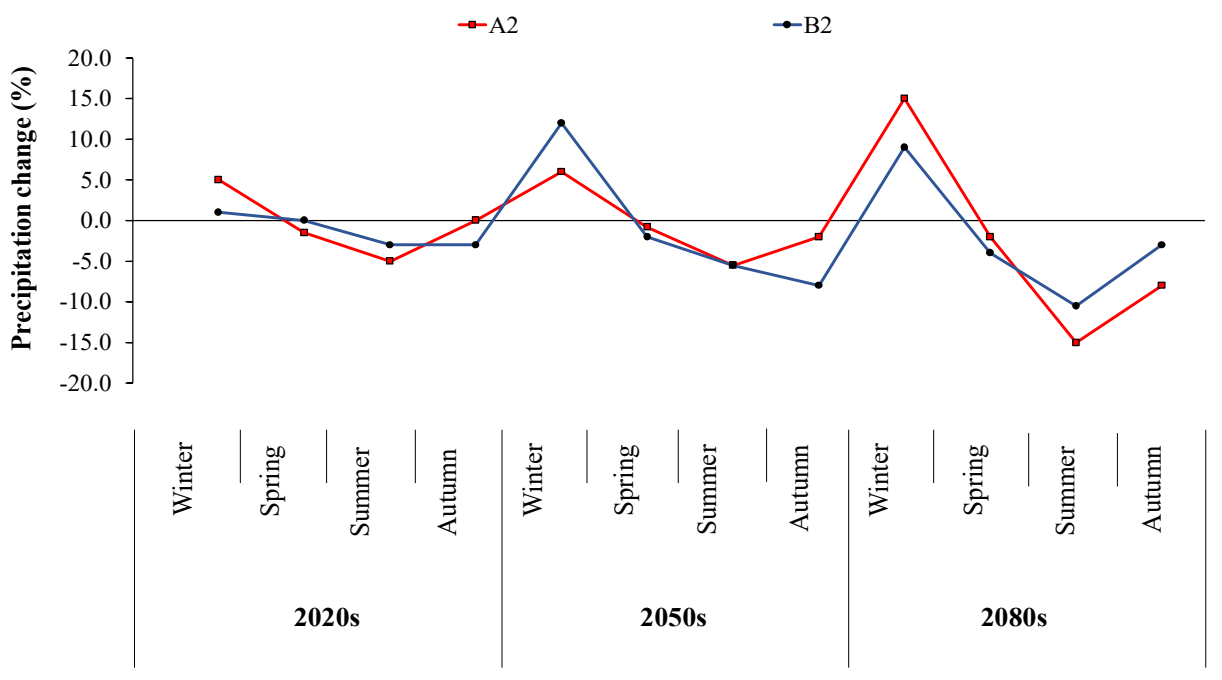

Figure 11. Changes in precipitation IPCC SERS A2 and B2 scenarios from the 2020s to 2080s. 


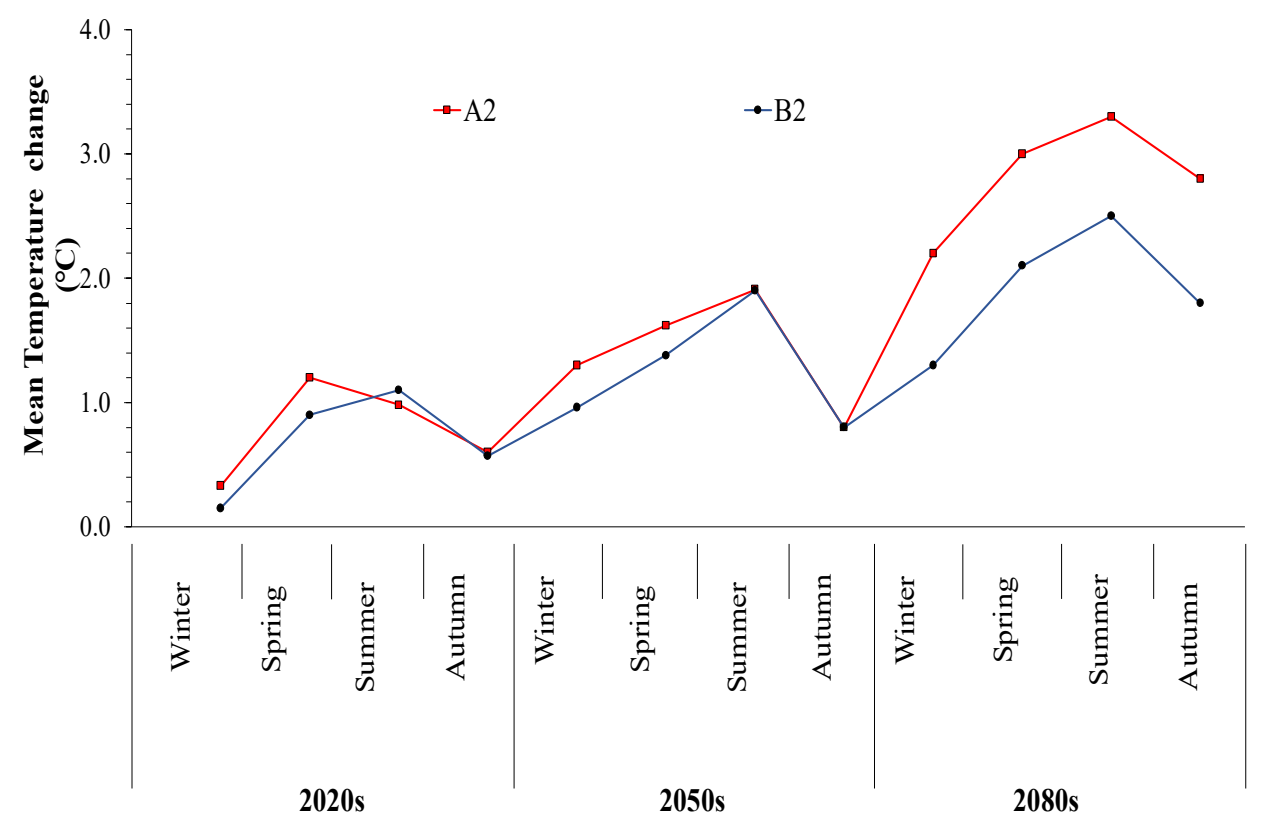

Figure 12. Changes in temperature under IPCC SERS A2 and B2 scenarios from the 2020s to 2080 s.

\section{Conclusions}

Snow cover research is critical for climatological and hydrological studies. The daily temperature, snow-covered, and precipitation were chosen as input data to simulate the snow melting runoff using SRM model. The simulated and observed runoff value was evaluated by the SRM model of the Lidder catchment. The SRM model results indicated with $R 2$ value of $0.96,0.92,0.95,0.90$ and 0.94 , respectively, for 2009-14 during calibration and validation period, while the Dv was found; $11.7,-10.1,-11.8,1.96$ and 8.6, respectively. For all simulated years, the average $\mathrm{R}^{2}$ value was 0.93 , and the average $\mathrm{Dv}$ value was $0.072 \%$. The simulated monthly discharge was in close agreement with the observed values in calibration and validation periods. A $20 \%$ rise in precipitation might result in a $37 \%$ increase in the runoff, according to a climatic scenario. The temperature rises of $2^{\circ} \mathrm{C}$ resulted in a $53 \%$ rise in catchment discharge and a $20 \%$ rise in snow cover. With the temperature rise of $2^{\circ} \mathrm{C}$ and an increase in snow cover by $20 \%$, the peak discharge was shifted by one month earlier (June) with a flow rate of $2944.30 \mathrm{~m}^{3} / \mathrm{s}$ as compared to the earlier peak discharge observed in July $\left(2013.44 \mathrm{~m}^{3} / \mathrm{s}\right)$. The SRM model shows that climate change's influence of precipitation and temperature on runoff is considerable with the premise developed. With increasing snow cover area, spring and summer streamflow is projected to rise. A $20 \%$ increase in snow cover causes the average streamflow during the snowmelt seasons to rise by $12.6 \%$. The results revealed that the SRM model is the best method for quantifying runoff due to the snowmelt, numerous processes linked to hydrology, climate, and ecology in mountainous and ungauged places.

Author Contributions: "Conceptualization, S.M. and R.K.; methodology, R.K.; software, S.K.; validation, S.K., R.K. and D.K.V.; formal analysis, S.M.; investigation, R.KX.; resources, R.K.; data curation, S.M.; writing-original draft preparation, S.M. and DKV; writing-review and editing, R.K., N.L.K., S.S., A.K. and A.E.; visualization, S.M. and D.K.V.; supervision, R.K.; project administration, R.K.; funding acquisition, A.E. and A.K. All authors have read and agreed to the published version of the manuscript. 
Funding: This research received no external funding.

Data Availability Statement: Not applicable.

Acknowledgments: The authors are highly thankful to the College of Agricultural Engineering and Technology, Sher-e-Kashmir University of Agricultural Sciences and Technology of Kashmir, Shalimar Campus Srinagar-190025 for providing all necessary facilities to conduct this study. The authors gratefully acknowledge the critical reviews of anonymous reviewers and the editor, which improved the manuscript significantly.

Conflicts of Interest: The authors declare no conflict of interest.

\section{References}

1. Jeelani, G.; Bhat, N.A.; Shivanna, K. Use of d18O tracer to identify stream and spring origins of a mountainous catchment: A case study from Liddar watershed, Western Himalaya, India. J. Hydrol. 2010, 393, 257-264.

2. Jeelani, G.; Feddema, J.J.; van der Veen, C.J.; Stearns, L. Role of snow and glacier melt in controlling river hydrology in Liddar watershed (western Himalaya) under current and future climate. Water Resour. Res.2012, 48, W12508, doi:10.1029/2011WR011590.

3. Aggarwal, S.P.; Thakur, P.; Nikam, B.; Garg, V. Integrated approach for snowmelt runoff estimation using temperature index model, remote sensing, and GIS. Curr. Sci.2014, 106, 397-407.

4. Kushwaha, N.L.; Bhardwaj, A.; Verma, V.K. Hydrologic response of Takarla-Ballowal watershed in Shivalik foot-hills based on morphometric analysis using remote sensing and GIS. J. Indian Water Resour. Soc. 2016, 36, 17-25.

5. Jai, S.K.; Goswami, A.; Saraf, A. Snowmelt runoff modeling in a Himalayan basin with the aid of satellite data. Int. J. Rem. Sens.2009, 31. 6603-6618.

6. Naser, S. Modeling and isotopic studies for assessment of contribution of snow/glacier melt in Parvati Basin, Himachal Pradesh. Am. J. Geol. Ecol.2013, 3, 2568-5449.

7. Mote, P.W.; Hamlet, A.F.; Clark, M.P.; Lettenmaier, D.P. Declining Mountain snowpack in western North America. Bull. Am. Met. Soc.2005, 86, 39-49.

8. Stewart, I.T. Changes in snowpack and snowmelt runoff for key mountain regions. J. Hydrol. Proc. 2009, 23, 78-94.

9. Knowles, P.; Dettinger, M.D.; Cayan, D.R. Trends in snowfall versus rainfall in the western United States. J. Clim.2006, 19, 4545-4559.

10. Ahluwalia, R.S.; Rai, S.P.; Jain, S.K.; Kumar, B.; Dobhal, D.P. Assessment of snowmelt runoff modeling and isotope analysis: a case study from the western Himalaya, India. Ann. Glaciol.2013, 54, 299-304

11. Rood, S.B.; Pan, J.; Gill, K.M.; Franks, C.G.; Samuelson, G.M.; Sheperd, A. Declining summer flows of Rocky Mountain rivers: changing seasonal hydrology and probable impacts on floodplain forests. J. Hydrol.2008, 349, 397-410.

12. Maurer, E.P.; Rhoads, J.D.; Dubayah, R.O.; Lettenmaier, D.P. Evaluation of the snow-covered area data product from MODIS. J. Hydrol. Proc.2003, 17, 59-71.

13. Shekhar, M.S.; Chand, H.; Kumar, S. Climate-change studies in the western Himalaya. Ann. Glaciol.2010, 51, 105-112.

14. Bhutiyani, M.R.; Kale, V.S.; Pawar, N.J. Changing streamflow patterns in the rivers of northwestern Himalaya: Implications of global warming in the 20th century. Curr. Sci.2008, 95, 618-626.

15. IPCC. Climate Change 2007: Synthesis report. Contribution of working groups I, II and III to the fourth assessment report of the intergovernmental panel on climate change. Core Writing Team, Pachauri, R.K., Reisinger, A. (Eds.), Intergovernmental Panel on Climate Change (IPCC), Geneva, Switzerland, 2007.

16. Jianchu, X. The melting Himalayas. Climate Change Impacts on High-Altitude Ecosystems. J. Natural Hazards Ear. Syst. Sci.2007, 5, 173-187. 
17. Tekeli, A.E.; Akyürek, Z.; ArdaSorman, A.; Sensoy, A.; Sorman, A. Using MODIS snow cover maps in modeling snowmelt runoff process in the eastern part of Turkey. Rem. Sens. Environ.2005, 97, 216-230.

18. Romshoo, S.A.; Rafiq, M.; Rashid, I. Spatio-temporal variation of land surface temperature and temperature lapse rate over mountainous Kashmir Himalaya. J. Mt. Sci.2018, 15, 563-576.

19. Bales, R.C.; Molotch, N.P.; Painter, T.H.; Dettinger, M.D.; Rice, R.; Dozier, J. Mountain hydrology of the western United States. Water Resour. Res.2006, 42, W08432,

20. Wagener, T.; Wheater, H.S.; Gupta, H.V. Rainfall-Runoff Modeling in Gauged and Ungauged Catchments, Imperial College press, 2004.

21. Tanmoyee, B.; Raju, P.V.; Abdul, H. Climate change impact on snowmelt runoff modeling for Alaknanda River Basin. J. Environ. Earth Sci.2015, 5, 56-67.

22. Singh, V.P.; Woolhiser, D.A. Mathematical modeling of watershed hydrology. J. Hydrol. Eng.2002, 7, $270-292$.

23. Wheater, H. Modeling hydrological processes in arid and semi arid areas: an Introduction. Hydrological Modeling in Arid and Semi Arid Areas. Cambridge University Press, 2008.

24. Martinec, J.; Rango, A.; Roberts, R. Snowmelt-runoff model (SRM) user's manual. USDA Jornada Experimental Range, New Mexico State University, Las Cruces, NM 88003, U.S.A, 2007.

25. Jain, S.K.; Goswami, A.; Saraf, A.K. Snowmelt runoff modelling in a Himalayan basin with the aid of satellite data. Int. J. Rem. Sens.2010, 31, 6603-6618.

26. Javadinejad, S.; Dara, R.; Jafary, F. Climate Change Scenarios and Effects on Snow-Melt Runoff. Civil Eng. J.2020, 6, $1715-1725$.

27. Abudu, S.; Cui, C.; Saydi, M.; King, J.P. Application of snowmelt runoff model (SRM) in mountainous watersheds: A review. J. Water Sci. Eng. 2012, 5, 123-136.

28. Mehdi, F.; Mehdi, J. The Estimation of Snowmelt Runoff Using SRM Case Study (Gharasoo Basin, Iran). J. World Appl. Sci.2012, 17, 433-438.

29. Kaul, M.N. Glacial and Fluvial Geomorphology of Western Himalaya: Liddar Valley, Concept, New Delhi, 1990.

30. Bolch, T. The state and fate of Himalayan glaciers. Curr. Sci.2012, 336, 310-314.

31. Scherler, D.; Bookhagen, B.; Strecker, M.R. Spatially variable response of Himalayan glaciers to climate change affected by debris cover. J. National Geosci.2011, 549, 156-159.

32. Martinec, J. Snowmelt-Runoff Model for stream flow forecasts. Nordic Hydrol.1975, 6, 145-154.

33. Butt, M.J.; Bilal, M. Application of snowmelt runoff model for water resource management. J. Hydrol. Proc.2011,25 3735-3747

34. Georgievsky, M.V. Application of the snowmelt runoff model in the Kuban river basin using MODIS satellite images. Environ. Res. Letters 2009, 4, 1-5.

35. Li, X.; Williams, M.W. Snowmelt runoff modeling in an arid mountain watershed, Tarim Basin, China. J. Hydrol. Proc.2008, 19, 1195-1203.

36. Tahir, A.A.; Chevallier, P.; Arnaud, Y.; Neppel, A.; Bashir, A. Modeling snowmelt-runoff under climate scenarios in the Hunza River basin, Karakoram Range, Northern Pakistan. J. Hydrol. 2011, 409, 104-117.

37. Singh, P.; Kumar, N. Effect of Orography on Precipitation in the Western Himalayan Region. J. Hydrol.1997, 199, 183-206.

38. Prasad, V.H.; Roy, P.S. Estimation of snowmelt runoff in Beas Basin, India. Geocarto Int.2005, 20, 41-47.

39. Akhtar, M.; Ahmad, N.; Booij, M.J. The Impact of Climate Change on the Water Resources of Hindukush-Karakorum-Himalaya Region under Different Glacier Coverage Scenarios. J. Hydrol.2008, 355, 148-163.

40. Cannone, N.; Wagner, D.; Hubberten, H.W.; Guglielmin, M. Biotic and abiotic factors influencing soil properties across a latitudinal gradient in Victoria Land, Antarctica. Geoderma.2008, 144, 50-65. 
41. Shukla, R.; Kumar, P.; Vishwakarma, D.K.; Ali, R.; Kumar, R.; Kuriqi, A. Modeling of stage-discharge using back propagation ANN-, ANFIS-, and WANN-based computing techniques. Theor Appl Climatol 2021. 